\title{
Comparison of Diagnostic Accuracy of Tuberculosis Spondylitis between GeneXpert and Histopathological Examination
}

\author{
David Rudianto Salim, Ahmad Ramdan, Gibran Tristan Alpharian \\ Department of Orthopaedic and Traumatology Faculty of Medicine Universitas Padjadjaran \\ Dr. Hasan Sadikin General Hospital Bandung, Indonesia
}

\begin{abstract}
Tuberculosis is an infectious disease caused by Mycobacterium tuberculosis. Spinal TB is associated with poor functional outcomes. Histopathological examination requires a long waiting times to obtain the results thus impractical for screening and may delay diagnosis. GeneXpert offers rapid tests for prompt screening and diagnosis. This study aimed to assess the diagnostic accuracy of GeneXpert in patients with spinal TB when compared to the histopathology test as the gold standard. This study was performed on patients in the Spine Clinic of the Department of Orthopedic and Traumatology, Dr. Hasan Sadikin General Hospital Bandung who were diagnosed with spinal TB during the period of May 2019-May 2020. Blood samples were collected from the patients and tested using GeneXpert and histopathological assessment. Results demonstrated 34 patients with a positive result and 6 patients with negative results on both diagnostic methods. Twenty nine out of 40 patients (72.5\%) had rifampin-sensitive TB. Diagnostic accuracy of GeneXpert, when compared to histopathological examination, is represented by the sensitivity of $88.2 \%$, specificity of $33.3 \%$, positive predictive value of $88.2 \%$, and negative predictive value of 33.3\%. High sensitivity results forpatients with spinal TB on GeneXpert suggests that the test is appropriate to be used as a screening method and as a high-yield rapid diagnostic test for patients suspected for spinal TB.
\end{abstract}

Keywords: Diagnostic, histopathology, GeneXpert, spondylitis TB

\section{Perbandingan Akurasi Diagnosis antara GeneXpert dan Pemeriksaan Histopatologi pada Tuberkulosis Tulang Belakang}

\begin{abstract}
Abstrak
Tuberkulosis adalah penyakit menular yang disebabkan oleh kuman Mycobacterium tuberculosis. Terjadinya TB tulang belakang terkait dengan penurunan fungsi motorik dalam jangka panjang. GeneXpert merupakan alternatif metode diagnostik yang lebih cepat dari pemeriksaan dengan kultur. Penelitian ini bertujuan untuk menilai akurasi diagnosis GeneXpert terhadap pasien dengan TB tulang belakang dengan pemeriksaan histopatologi sebagai standar baku. Penelitian bertujuan membandingkan akurasi diagnosis GeneXpert terhadap pemeriksaan histopatologi pada pasien dengan TB tulang belakang. Pasien dengan diagnosis TB tulang belakang yang berobat ke poli tulang belakang Departemen Orthopaedi dan Traumatologi Rumah Sakit Dr. Hasan Sadikin Bandung pada Mei 2019-Mei 2020 merupakan kriteria inklusi pasien. Pengambilan sampel darah dilakukan untuk pemeriksaan GeneXpert dan histopatologi. Terdapat 34 pasien dengan hasil positif dan 6 pasien dengan hasil negatif pada pemeriksaan GenXpert dan histopatologi. Terdapat 29 dari 40 pasien (72,5\%) yang sensitif terhadap rifampin. Akurasi diagnostik GeneXpert (dibanding dengan pemeriksaan histopatologi): sensitivitas 88,2\%; spesifisitas 33,3\%; nilai prediktif positif $88,2 \%$; dan nilai prediktif negatif $33,3 \%$. Sensitivitas pemeriksaan yang tinggi pada pasien dengan TB tulang belakang menggunakan GeneXpert merupakan salah satu tanda bahwa metode diagnostik tersebut dapat digunakan sebagai alat skrining untuk diagnosis yang lebih cepat.
\end{abstract}

Kata kunci: Diagnostik, histopatologi, GeneXpert, spondilitis TB

Corresponding Author: David Rudianto Salim, Department of Orthopaedic and Traumatology Faculty of Medicine Universitas Padjadjaran/Dr. Hasan Sadikin General Hospital Bandung, Jalan Pasteur No 38 Bandung, West Java, Indonesia, Email: davidrsalim@gmail.com 


\section{Introduction}

Tuberculosis is a disease caused by the infection of Mycobacterium tuberculosis. Systemic and non-specific symptoms may be noted among TB patients, such as reduced appetite, unintentional weight loss, night sweats, fatigue, and chronic fever. ${ }^{1}$ This disease remains a prevalent problem worldwide. In 2016 alone, the prevalence rate of tuberculosis infection was 10.4 million, with an incidence rate of up to 120 cases per 100,000 individuals worldwide in the same year, making it the $10^{\text {th }}$ leading cause of death of the year. ${ }^{2}$ in 2010 there were 8.8 million new cases of tuberculosis (TB).

Despite the availability of effective TB treatment regimens, infection remains a prevalent problem. High caseloads were found particularly in the Southeast Asia region and Indonesia was in 5th place in TB prevalence rate in 2013, according to the World Health Organization (WHO). ${ }^{3}$ While tuberculosis infections are mainly confined to the pulmonary spaces, approximately a quarter of the cases may spread systematically. Such cases are defined as extrapulmonary TB. ${ }^{4}$ Data from the Department of Orthopaedics and Traumatology, Dr. Hasan Sadikin General Hospital Bandung, Indonesia, show that there are isolated cases of spinal TB infection without a previous history of lung TB infection. The department recorded 240 cases of spinal TB, with 80 cases required surgical management during the period of January 2014December 2018,5,6

Spinal TB cases are associated with higher rates of morbidity. Kyphotic deformities may occur in cases of spinal TB due to bone destruction of the vertebra. Sensory and motor deficits have been seen in $77.1 \%$ of cases of spinal TB. In severe cases, surgery is required to treat severe deformities, severe neurological deficits, and/ or to treat patients with paravertebral abscess. ${ }^{7}$ To prevent further complications associated with TB infection, early diagnosis which leads to early treatment is paramount to prevent further spread.

Confirmatory diagnosis of TB using culture from sputum sample is notably unsuitable for rapid screening. The primary limitation of the diagnostic method is the time needed to get the result, despite of its confirmatory nature. It may require weeks to get the result and to completely confirm the diagnosis. As such, other alternative methods are developed to reduce the time needed to diagnose this disease.

One of these alternative method is the
GeneXpert. GeneXpert is a rapid molecular test designed to provide semi-quantitative results in TB diagnosis, offering faster diagnostic results without any significant sacrifice to the diagnostic accuracy. The high throughput of GeneXpert, without significantly sacrificing diagnostic accuracy, is the primary advantage of GeneExpert compared to the previous gold standard. This study aimed to compare the diagnostic accuracy of GeneXpert to the histopathological examination in diagnosing spinal TB cases in Indonesia.

\section{Methods}

A cross-sectional study was conducted in Dr. Hasan Sadikin General Hospital Bandung, Indonesia. This study included patients with a previous spinal TB diagnosis with a confirmatory diagnosis of TB infection using histopathological examination and GeneXpert. Retrospective analysis of adult patients (15-65 years old) diagnosed with spinal TB and/or paravertebral abscess in this hospital from February 2020May 2020 was included herein. Patients with relapsed spinal TB and without paravertebral abscess were excluded from the study. The Ethical Committee of Dr. Hasan Sadikin General Hospital approved the study before its commencement with the issuance of the ethical clearance number LB.02.01/X.65/95/2020.

Variables collected from the study were acquired retrospectively from medical records on patients receiving spinal surgery for spinal TB and paravertebral abscess. Then, informed consent before the surgery and usage of pus samples (obtained intra-operatively) were obtained. Abscess drainage was performed during the surgery. Subsequently, the samples obtained were sent to the laboratory for GeneXpert and histopathological examination. The examination results using each method were then stratified according to the results (positive or negative).

Normality tests and differences of both diagnostic methods were applied to identify any significant differences between both methods. The Shapiro-Wilk normality test was used to determine the normality of numeric variables of the study. Numerical data with non-normal distribution were described in median and numerical data with normal distribution were described in mean and range. The chi-square test was used to compare the significant difference between the positive diagnosis in both methods 
Table 1 Baseline Characteristics

\begin{tabular}{lc}
\hline \multicolumn{1}{r}{ Variable } & n (\%) \\
\hline Age (years) & \\
$<20$ & $1(2.5)$ \\
$20-29$ & $6(15)$ \\
$30-39$ & $11(27.5)$ \\
$40-49$ & $9(22.5)$ \\
$50-59$ & $4(10)$ \\
$\geq 60$ & $9(22.5)$ \\
Sex & \\
Male & $26(65)$ \\
Female & $14(35)$ \\
\hline
\end{tabular}

with a p-value of $<0.05$ was deemed significant.

\section{Results}

Forty patients were included in the study with most of them were in the age group of 30-39 years old $(27.5 \%)$, followed by $40-49$ years old $(22.5 \%)$ and over 60 years old $(22.5 \%)$ with the mean age of 47.45 years old. There were 26 male patients (65\%) and 14 female patients (35\%) included in this study, and 29 patients $(72.5 \%)$ sufferred from rifampin-sensitive TB, according to the medical records.

Patients included in the study had received diagnosis based on both histopathological and GeneXpert testing. In comparison with histopathology examination, GeneXpert examination had a significantly higher positive diagnosis compared to the histopathology results $(p=0.001)$. The diagnostic accuracy of GeneXpert, when compared to the histopathology examination as the gold standard, was as follows: sensitivity $88.2 \%$, specificity $33.3 \%$, positive predictive value $88.2 \%$, and negative predictive value $33.3 \%$. Sensitivity and positive predictive value for GeneXpert examination were high in the detection of patients with spinal tuberculosis.

\section{Discussion}

GeneXpert is a rapid diagnostic method for TB infections. The test was developed as a response to alleviate the main weakness of diagnostic confirmation using culture samples, which is time constraint. Increased prevalence and incidence of TB cases, despite the availability of antituberculosis drugs and regimens in developing countries, require rapid diagnostic methods to be developed to aid the management and prevention of the further spread of TB. This is particularly important in low-resource settings often faced in developing countries. ${ }^{8}$ GeneXpert, as a screening tool, has sufficiently high sensitivity concerning its rapidity to generate test results. A previous study by Norin et al. had noted the following for the diagnostic accuracy parameters in GeneXpert for detection of $M$. tuberculosis: sensitivity $79.6 \%$, specificity $97.1 \%$, positive predictive value $88 \%$, and negative predictive value $94.6 \%$. In cases of extrapulmonary $\mathrm{TB}$, the diagnostic accuracy of GeneXpert may be relatively reduced. In the same study, a reduction of sensitivity to $60 \%$ and a positive predictive value of $60 \%$ were noted. The specificity and negative predictive value of the test increase to $95.4 \%$ and $95.4 \%$, respectively. ${ }^{9}$ Similar results were discovered herein when compared to the study above. It is possible that, due to the study's limitation, decreased specificity and negative predictive value found in this study are due to the low number of samples collected for the study.

Despite its relatively high sensitivity and suitability in the screening tool, GeneXpert has a risk of increased overestimation in regions with low TB incidence. ${ }^{7,10}$ Additionally, for extrapulmonary TB cases, such as in South Africa, this method has been reported to have lower sensitivity yet with higher specificity. The

Table 2 Comparison of Diagnostic Accuracy between GeneXpert and Histopathology Examination

\begin{tabular}{lcccc}
\hline & \multicolumn{2}{c}{ Histopathology } & \multirow{2}{*}{ Total } & p-value \\
\cline { 2 - 3 } & Negative & Positive & & 0.001 \\
GeneXpert & $2(50.0 \%)$ & $1(2.8 \%)$ & $3(5.0 \%)$ & \\
Positive & $2(50.0 \%)$ & $35(97.2 \%)$ & $37(92.5 \%)$ & \\
Negative & $4(100.0 \%)$ & $36(90.0 \%)$ & $40(100 \%)$ & \\
\hline
\end{tabular}


study in South Africa presumed the possibility of sample contamination that may lead to altered accuracy of the test in comparison to the samples diagnosed using culture samples. ${ }^{11}$ There are also several previous studies on GeneXpert diagnostic accuracy in diagnosing patients with spinal TB that have ben conducted. A previous study by Held et al. reported a high level of sensitivity (95.6\%) and specificity (96.2\%), with drastically faster diagnostic results. GeneXpert diagnostic results can be attained in 2 days, while the median time to diagnosis in culture studies is 35 days (interquartile range of 15-42 days). ${ }^{12}$ Previous studies analyzing the accuracy of GeneXpert in the diagnosis of spinal TB have shown mixed results. Regardless, the present study's results demonstrate high sensitivity and positive predictive value, yet with low specificity and negative predictive value.

This study has several limitations. In comparison to previous studies analyzing the diagnostic accuracy of GeneXpert and spinal $\mathrm{TB}$, the current study has a lower sample size (40 patients). Also, the GeneXpert diagnostic method may detect damaged MTB, resulting in a risk for gaining false-positive results. Specifically, this study analyzes the diagnostic accuracy of GeneXpert with a blood sample from patients with spinal TB. Blood culture samples are known to be less accurate compared to sputum samples. However, despite this limitation, this study is one of the few studies in Indonesia specifically addressing the usability of GeneXpert in diagnosing extrapulmonary TB cases with a specific focus on spinal TB. Future studies, preferably with further follow-ups, are required to further elucidate the function and feasibility of GeneXpert in diagnosing extrapulmonary TB in Indonesia. In conclusion, GeneXpert should be utilized as a diagnostic tool to screen and detect patients with spinal TB. Further studies may be required to assess the feasibility of rapid molecular testing methods in low-resource and high-incidence regions, specifically in Indonesia.

\section{References}

1. Pellisé F. Tuberculosis and Pott's disease, still very relevant health problems. Eur Spine J. 2013;22(Suppl 4):527-8.

2. Millet JP, Moreno A, Fina L, Baño L Del, Orcau A, De Olalla PG, et al. Factors that influence current tuberculosis epidemiology. Eur Spine J. 2013;22 Suppl 4(Suppl 4):539-48.

3. WHO (Global Tuberculosis Programme). Global tuberculosis report 2020. Geneva: World Health Organization; 2020. p. 232.

4. Paton NI, Borand L, Benedicto J, Kyi MM, Mahmud AM, Norazmi MN, et al. Diagnosis and management of latent tuberculosis infection in Asia: Review of current status and challenges. Int J Infect Dis. 2019;87:219.

5. Merza M, Farnia P, Anoosheh S, Varahram M, Kazampour M, Pajand O, et al. The NRAMPI, VDR and TNF-alpha gene polymorphisms in Iranian tuberculosis patients: the study on host susceptibility. Brazilian J Infect Dis. 2009;13(4):252-6.

6. Nataprawira $\mathrm{H}$, Rahim A, Dewi M, Ismail Y. Comparation between operative and conservative therapy of spondylitis tuberculosis in Hasan Sadikin Hospital Bandung.J Indones Med Assoc. 2011;60(7):6.

7. Rasouli MR, Mirkoohi M, Vaccaro AR, Yarandi KK, Rahimi-Movaghar V. Spinal tuberculosis: diagnosis and management. Asian Spine J. 2012;6(4):294-308.

8. Agrawal M. Comparative study of genexpert with ZN stain and culture in samples of suspected pulmonary tuberculosis. J Clin Diagnostic Res. 2016;10(5):DC09-12.

9. Le Palud P, Cattoir V, Malbruny B, Magnier R, Campbell K, Oulkhouir Y, et al. Retrospective observational study of diagnostic accuracy of the Xpert@ MTB/RIF assay on fiberoptic bronchoscopy sampling for early diagnosis of smear-negative or sputum-scarce patients with suspected tuberculosis. BMC Pulm Med. 2014;14(1):137.

10. Solanki AM, Basu S, Biswas A, Roy S, Banta A. Sensitivity and specificity of gene Xpert in the diagnosis of spinal tuberculosis: a prospective controlled clinical study. Glob Spine J. 2020;10(5):553-8.

11. Scott LE, Beylis N, Nicol M, Nkuna G, Molapo $S$, Berrie L, et al. Diagnostic accuracy of Xpert MTB/RIF for extrapulmonary tuberculosis specimens: establishing a laboratory testing algorithm for South Africa. J Clin Microbiol. 2014;52(6):1818-23.

12. Held M, Laubscher M, Zar HJ, Dunn RN. GeneXpert polymerase chain reaction for spinal tuberculosis. Bone Joint J. 2014;96$\mathrm{B}(10): 1366-9$. 